\title{
Environmental impact assessment of a turboprop engine with the aid of exergy
}

\author{
Ramazan Atılgan ${ }^{a}$, Önder Turan ${ }^{\mathrm{a}, *}$, Önder Altuntaş ${ }^{\mathrm{a}}$, Hakan Aydın ${ }^{\mathrm{b}}$, Kateryna Synylo ${ }^{\mathrm{c}}$ \\ ${ }^{a}$ Faculty of Aeronautics and Astronautics, Anadolu University, TR-26470 Eskisehir, Turkey \\ ${ }^{\mathrm{b}}$ TUSAS Engine Industries, Eskisehir, Turkey \\ ${ }^{\mathrm{c}}$ National Aviation University, Kyiv, Ukraine
}

\section{A R T I C L E I N F O}

\section{Article history:}

Received 22 March 2013

Received in revised form

20 May 2013

Accepted 21 May 2013

Available online 30 June 2013

\section{Keywords:}

Exergo-environmental analysis

Regional aircraft

Turboprop

Exergy

Life cycle assessment

\begin{abstract}
A B S T R A C T
To develop approaches that effectively reduce engine environmental effect of aircrafts, it is necessary to understand the mechanisms that have enabled improvements in thermodynamic efficiency of aircraft engines. In the present work, a turboprop engine used in regional aircrafts that produces $1948 \mathrm{shp}$ and 640 N.m torque is examined using exergo-environmental method. The results show compressor, combustion chamber, gas generator turbine, power turbine and exhaust nozzle create $9 \%, 69 \%, 13 \%, 7 \%, 2 \%$ of total environmental impact of the engine, respectively. According to rates, the compressor and gas turbine can be considered first to improve in case of component related environmental impact. Furthermore, total component related environmental impact for the turboprop engine is found to be $2.26 \mathrm{mPts} / \mathrm{s}$ for the constructional phase and $2.34 \mathrm{mPts} / \mathrm{s}$ for the operation/maintenance phases. Accordingly, it is suggested that, in order to estimate environmental impact metric of aircrafts, the exergo-environmental analysis can be employed for aircraft propulsion systems.
\end{abstract}

(c) 2013 Elsevier Ltd. All rights reserved.

\section{Introduction}

Passenger traffic in aviation sector around the world will grow $5.1 \%$ annually. This growth will require new aircrafts and more flights. Moreover, consequences of the passenger traffic growth are a significant escalation in harmful jet engine emissions, unprecedented traffic jams, nonstop noise around the airports, and negative effects on people health and their quality of life. In order to eliminate as much potential harm to the environment as possible and make air transportation more efficient, scientist must closely work with government and industry on green and sustainable aviation initiatives [1-6].

Aviation is responsible for approximately $2 \%$ of total global greenhouse gases (GHG) emissions. This contribution is a result of $2-3 \%$ of total fossil fuel consumption worldwide. If the current growth rate of air travel continues, this trend is forecast to grow to around $3 \%$ by 2050 [7].

During last decade a lot of studies are also focusing on the aircraft emissions impact on local and regional air quality in the

\footnotetext{
* Corresponding author. Tel.: +90 222 3350580; fax: +90 2223221619.

E-mail addresses: ratilgan@anadolu.edu.tr (R. Atılgan), science.onder.turan@ gmail.com, onderturan@anadolu.edu.tr (Ö. Turan), oaltuntas@anadolu.edu.tr (Ö. Altuntaş), tei.hakan@gmail.com (H. Aydın), synyka@gmail.com (K. Synylo).
}

vicinity of airport. Aircraft (during approach, landing, taxi, take-off and initial climb of the aircraft, engine run-ups, etc.) is the dominant source of air pollution at airport. According to inventory results the part of adverse exhausts from aircraft is 50\% of the total mass of emissions in the airport area. Currently the basic objects of attention are $\mathrm{NO}_{x}$ and fine particle matter (PM) emissions from aircraft engine emissions as initiators of photochemical smog and regional haze, which further direct impact on human health. Significant concerns regarding regional air pollution around the airports remain especially for city airports, which are quite closely located to habitation area, so impact of aircraft emissions on urban air quality is high. Air transport GHG, $\mathrm{NO}_{x}$ and $\mathrm{PM}$ emissions could be lowered by reducing activity, improving the energy efficiency of transport modes [8-10]. The aviation industry has successfully made consistent, continued efforts to reduce the fuel burn, emissions and noise produced by aircrafts. To reduce environmental impacts of aircrafts, GHG, $\mathrm{NO}_{x}$ and PM emissions should be minimized and that can be accomplished by maximizing the energy efficiency of aircraft propulsion systems [11].

Energy is an important tool for the sustainable environment. The importance of energy efficiency for green aviation is also linked to environmental problems, such as global warming, noise and atmospheric pollution [12,13]. Therefore, energy consumption plays a crucial role to achieve green aviation development. Energy efficiency is a useful metric for evaluating aircraft environmental 
performance. Moreover, technology has a vital role to play in mitigating the environmental impacts of air transport. If so, the most direct way for an airline to improve its fuel efficiency with new aircraft and its components incorporating the latest available technology [14-16]. Technical measures as aircraft and engine technology improvements have much potential for reducing emissions. The latest aircraft and engine designs are significantly more fuel efficient than previous generations of aircraft (on average, a 1-2\% fuel efficiency improvement per annum). However, due to the average (economic) lifetime of 20-30 years of an aircraft the full benefit of current new engine and aircraft technology will take decades. With the possible exception of Fisher-Tropsch fuel, the development and widespread use of alternative fuels may also take decades. Therefore, the potential usefulness of energy analysis for aircraft engines in addressing environmental issues is substantial [17-22].

Energy and exergy concepts have been utilized to ensure the environmental sustainability. In order to reduce the negative impacts created by the pollutant emissions, the energy sources should be efficiently utilized. There are two environmental considerations incorporated with environment and thermodynamics: energy and exergy analysis [18]. Exergy as the thermodynamic departure between a substance and its surrounding has been gradually accepted as a unified measure for the environmental impact of waste emissions [23-25]. Wall [26] suggested exergy as a suitable measure of environmental impact of waste emissions. There have been various assessment used for waste gases emitted from transportation sectors $[27,28]$. The exergy of an emission to the environment, therefore, is a measure of the potential of the emission to change or impact the environment. These points suggest that exergy may be an effective indicator of the potential of an emission to impact the environment [21].

Growing focus on emissions and noise along with high fuel prices are favouring turboprops demand growth. In 2010 there were 2080 turboprops in service with an average age of 15 years. By 2030 , a total of 2440 new turboprops will be delivered and the total turboprop fleet will increase to 3295 aircraft. From 2011 to 2030, a total of 660 new turboprops will be delivered: 41\% to replace old aircraft and 59\% to support market growth [29]. Between 2010 and 2029 , Embraer forecasts that $32 \%$ of aircraft deliveries in the $30-$ 120 seat range will be turboprops and Bombardier forecasts that $39 \%$ of aircraft deliveries in the 20-99 seat range will be turboprops [30]. The latest technology turboprops will remain an essential part of the world's regional aircraft fleet. The high fuel prices have highlighted one of the principal benefits of the twin turboprop over the regional jet: its low fuel consumption and unrivalled economics on short-haul connections. Since turboprops are more fuel efficient, increasing fuel prices could diminish the importance of passenger preference [22]. Turboprop usage on short-haul flights may increase due to a move to more fuel efficient technologies [31]. By using turboprop engines on an aircraft, the following advantages are yielded: (a) the engine can be run under more efficient and economical conditions at low and medium altitudes; (b) the amount of power available for propulsion is largely independent of the forward speed of the aircraft.

In this regard, the scientists, researchers, and engineers, who work on useful solutions for the aircraft gas turbine engines, aim at maximizing the energy saving, minimizing the energy consumption, and thus, developing the environmentally benign propulsion systems, which is reducing environmental impacts for sustainable aviation. If so, in terms of the second-law of thermodynamics, minimizing irreversibilities in the turboprop engines also becomes significant challenge for better efficiency, environment and sustainability.

Under these important considerations, a detailed literature review has been performed on exergy analysis [32,33]. The exergy studies related to gas turbine engines have been done on stationary gas turbines before. In the literature, the various exergy and exergoeconomic analysis of aero engines have been reported [31,34-44]. In terms of exergy analysis of the turboprop engines, Aydin et al. $[31,34]$ examined some exergetic aspects of the CT7 engine. Aydın et al. [31] measured and calculated operating mass flow rates, inlet and outlet temperatures and pressures, work and power of the turboprop engine and its components. Nevertheless, exergoenvironmental analyses have not been developed for turboprop engines.

Exergo-environmental analysis is a relatively new method, but it is widely used to assess environmental impact of numerous energy conversion systems. Altuntas et al. [45] investigated exergo-economic performances of piston-prop aircraft engines during landing and take-off phases of a flight. Ahmadi and Dincer [46] analyzed a gas turbine power plant, developed a simulation code and validated this code with comparing actual data obtained from a running gas turbine power plant. After optimization studies, they reported about $50.50 \%$ decrease in environmental impacts of the plant. Boyano et al. [47] examined a steam methane reforming reactor for hydrogen production, and performed both conventional and advanced exergo-environmental analysis. They also reported that environmental impact is the highest where chemical reaction occurs [48]. Meyer et al. [49] presented general methodology of exergo-environmental analysis and investigated a high-temperature solid oxide fuel cell (SOFC). Furthermore, they pointed out limitations of life cycle assessment (LCA) as an environmental assessment method. Ahmadi et al. [50] carried out an exergo-environmental analysis of a trigeneration system with a micro gas turbine engine. Petrakopoulou et al. [51] analyzed a combined cycle power plant and expressed that advanced exergybased methods should be performed beside conventional ones to get the most accurate results. Altuntas et al. [52] investigated a piston-prop aircraft engine for four different flight phases (takeoff, climb, approach and taxi). They proposed best air-to-fuel ratio/ altitude/power setting option that minimizes environmental impact. Restrepo et al. [53] presented an exergetic and environmental analysis of a pulverized coal power plant located in Brazil. They also reported that highest environmental impact rate is caused by power plant as a result of highest exergy destruction rate (95.6\% of overall exergy destruction of operation phase). Ahmadi and Dincer [54] modeled a combined heat and power (CHP) plant and performed exergo-environmental optimization of the plant. Results showed that higher isentropic efficiency of compressor and gas turbine causes less exergy destruction in compressor and gas turbine. This means lower fuel consumption, thus lower environmental impact and lower operating cost.

As can be seen in aviation sector, no study about exergoenvironmental analysis of a turboprop aircraft engine is appeared in the open literature and that is the main motivation for the authors. In this study, exergo-environmental analysis is chosen as a method to evaluate environmental performance of an aircraft turboprop engine. Lack of exergo-environmental aspect of the turboprop engine emphasizing the originality of this article is the motivation behind this study.

In summary, this work including important exergoenvironmental parameters of the turboprop engine at maximum power setting, aims to contribute to:

- determine component related environmental impacts of each turboprop engine components,

- calculate environmental impacts for each engine components result from exergy destructions,

- determine total environmental impacts of the engine components individually, 
- evaluate environmental performance of the turboprop engine and its components by calculating exergo-environmental variables.

\section{System description}

Engines that provide the shaft power required to drive the propeller from gas turbine engine can be defined as turboprop engine [55]. A turboprop engine produces two kind of thrust, first one is generated by propeller and the other one is through the exhaust gases. The thrust generated by propeller constitutes almost $85 \%$ of the total thrust while the remaining $15 \%$ is generated by jet engine core [56]. For better understanding the main operating principle and the main roles of the turboprop engine components, Fig. 1 is illustrated. Main components of the turboprop engine shown in this figure are axial/centrifugal compressor, combustor, gas generator turbine, power turbine and exhaust. The engine studied here can either be tested by its propeller and propeller gearbox or by dynamometer instead of propeller and propeller gearbox. The air is first taken through the bell mouth assembly. The free power turbine is connected to water brake dynamometer spline through the power turbine shaft so the power turbine rotates along with dynamometer shaft. The torque and power turbine speeds are calculated by engine and dynamometer sensors as well, these values are compared all along the test. The torque transferred by the power turbine shaft of the turboprop engine is accurately measured by detecting the angular deflection of the shaft and providing an electrical signal which is representative of the deflection [31]. To develop the exergo-environmental analysis of the turboprop engine, the first step should be to perform the exergy analysis of the engine. Actually, the main objective of this study is not to perform an exergy analysis for a turboprop engine. Such an analysis and more details on the turboprop engine can be found in the literature [31,34]. Parameters of the turboprop engine and its environment are given in the Table 1 used in the exergoenvironmental analysis.

\section{Analysis}

Exergo-environmental analysis can be defined as a combination of exergy analysis and LCA. This analysis consists of three steps. The first step is exergy analysis. In this step, inlet and outlet exergy flows of each engine component should be calculated in order to determine exergy destruction of each component. The second step is an LCA of the relevant components and the overall system. The last step is the assessing environmental impact of each component exergy stream $[57,58]$.

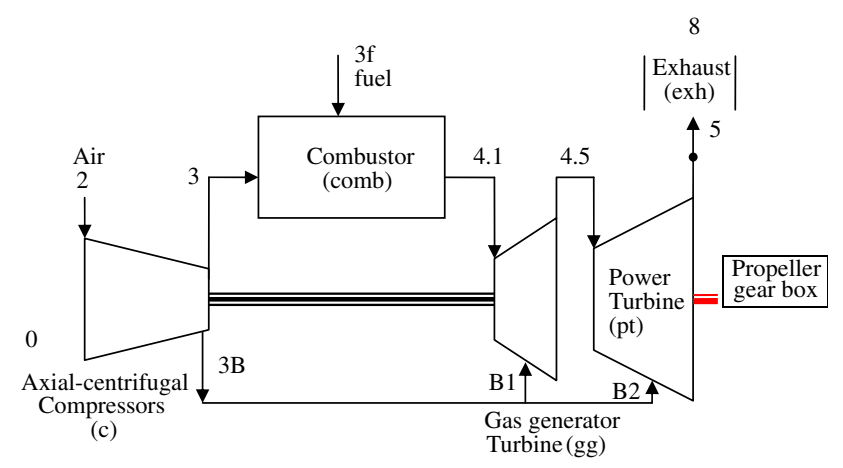

Fig. 1. Control volume of the turboprop engine.
Table 1

Turboprop engine parameters at ground operation.

\begin{tabular}{ll}
\hline Parameter & Value \\
\hline Atmospheric pressure (kPa) & 93 \\
Atmospheric temperature (K) & 279 \\
Humidity (\%) & 22.77 \\
Power turbine inlet temperature (K) & 1109 \\
Power turbine speed (RPM) & 22,011 \\
Gas generator speed (RPM) & 42,523 \\
Engine air flow $\left(\mathrm{kg} \mathrm{s}^{-1}\right)$ & 4.73 \\
Fuel (Jet-A1) heating value ( $\left.\mathrm{kJ} \mathrm{kg}^{-1}\right)$ & 43,400 \\
Fuel mass flow $\left(\mathrm{kg} \mathrm{s}^{-1}\right)$ & 0.1 \\
\hline
\end{tabular}

Source: [31].

\subsection{Exergy analysis}

Numerous ways of formulating energy and exergy for various energy systems are given in detail elsewhere. It is very useful to define performance parameters based on energy and exergy. Some of the parameters are obtained from engine ground test run. Since not all parameters are measured during testing, the remaining parameters have been calculated by parametrical cycle analysis. After obtaining all the temperature, pressure and flow mass values at each station the energy and exergy values have been calculated in the inlet and exit of engine components by using Table 2. More importantly, turboprop engine has been run at maximum power condition (for maximum power setting, engine torque value was observed as $630 \mathrm{~N} \mathrm{~m}$ ). Majority of the engine parameters are obtained from engine test ground run. Remaining few parameters has been calculated parametrically. The energy and exergy equations for the turboprop engine are shown in Table 3. Implementation to exergetic equations to the engine components, exergy values for every location are yielded as given in Table 4.

\subsection{Exergo-economic analysis}

Exergo-economic analysis is a unique combination of exergy analysis and cost analysis conducted at the component level, to provide the designer or operator of an energy conversion system with information crucial to the design of a cost-effective system. This information cannot be supplied through energy, exergy, and cost analyses conducted separately [34]. In exergo-economic analysis, cost of each exergy stream is determined. Inlet and outlet exergy streams of the each component are associated to a monetary cost. Similar to this, environmental cost of each exergy stream of the engine components is determined in exergoenvironmental analysis [59]. Exergo-economic aspect of the turboprop engine used in this study was analyzed by Aydin et al. [31]. Some Exergo-economic parameters are listed in Table 5. The purchased equipment cost (PEC) of the main engine components have been obtained by adding the average cost of all other engine equipment costs such as accessories, frames and gearbox. The component costs are approximately estimated ones and not

Table 2

Turboprop engine thermodynamic values.

\begin{tabular}{lllcr}
\hline Station & Station name & $\begin{array}{l}\text { Mass flow } \\
\left(\mathrm{kg} \mathrm{s}^{-1}\right)\end{array}$ & $\begin{array}{l}\text { Temperature } \\
(\mathrm{K})\end{array}$ & $\begin{array}{c}\text { Pressure } \\
(\mathrm{kPa})\end{array}$ \\
\hline 0 & Air & 4.73 & 279 & 93 \\
2 & Compressor inlet & 4.73 & 279 & 92 \\
3B, B1, B2 & Cooling air & 0.355 & 700 & 1600 \\
3 & Combustor inlet & 4.35 & 725 & 1638 \\
3f & Fuel & 0.1 & 279 & 3500 \\
4.1 & Combustor exit & 4.45 & 1547 & 1580 \\
4.5 & Power turbine inlet & 4.76 & 1109 & 332 \\
5 & Power turbine exit & 4.81 & 847 & 98 \\
\hline
\end{tabular}

Source: [31] 
Table 3

Energy and exergy balance equations of the turboprop engine.

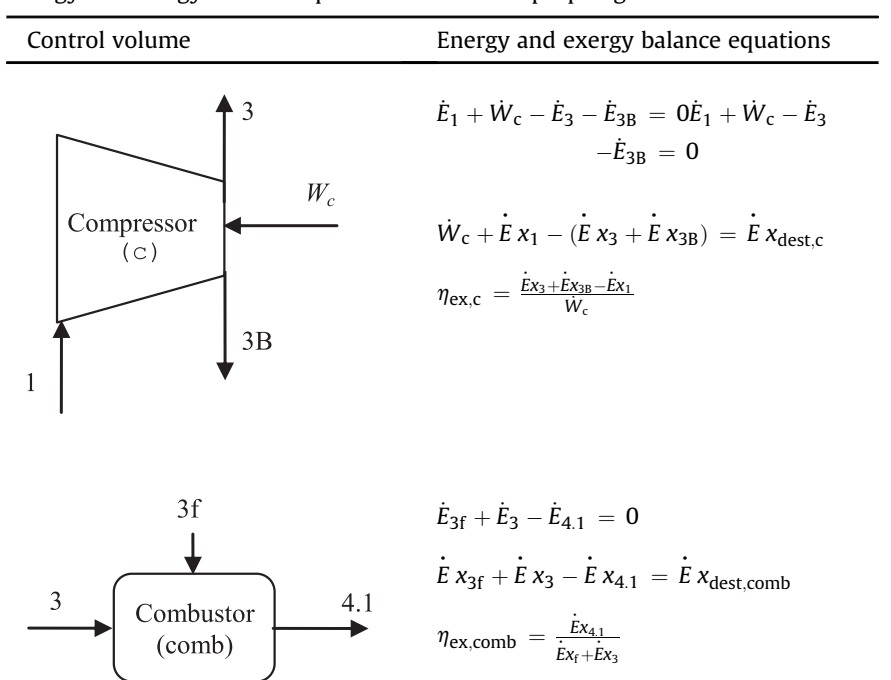

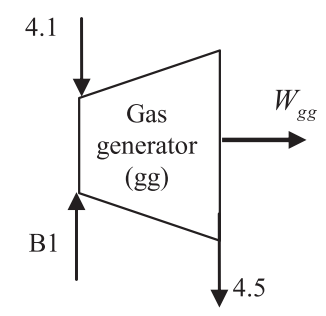

$$
\begin{aligned}
& \dot{E}_{4.1}+\dot{E}_{\mathrm{B} 1}-\dot{E}_{4.5}-\dot{W}_{\mathrm{gg}}=0 \\
& \dot{E} x_{4.1}+\dot{E} x_{\mathrm{B} 1}-\dot{E} x_{4.5}-\dot{W}_{\mathrm{gg}}=\dot{E} x_{\mathrm{dest}, \mathrm{gg}} \\
& \eta_{\mathrm{ex}, \mathrm{gg}}=\frac{\dot{W}_{\mathrm{gg}}}{\dot{E} x_{4.1}-\dot{E} x_{4.5}+\dot{E} x_{\mathrm{B} 1}}
\end{aligned}
$$

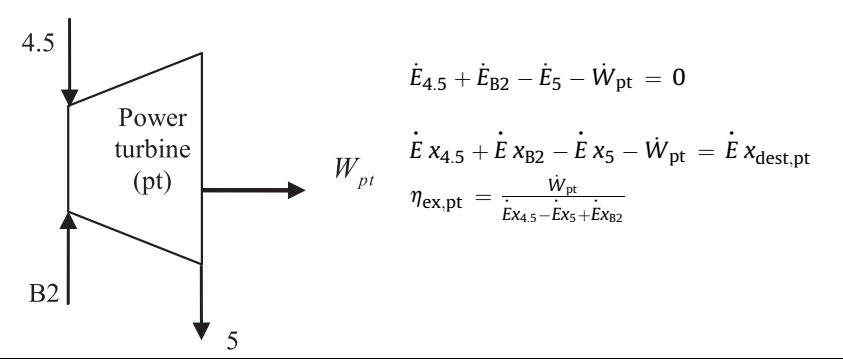

Table 4

Results obtained from the exergy analysis.

\begin{tabular}{lc}
\hline Component stations & Exergetic value $(\mathrm{kW})$ \\
\hline$\dot{E} x_{1}$ & 0 \\
$\dot{E} x_{3 \mathrm{~B}}$ & 102 \\
$\dot{E} x_{3}$ & 1952 \\
$\dot{W}_{\mathrm{C}}$ & 2450 \\
$\dot{E} x_{\text {dest }, \mathrm{C}}$ & 396 \\
$\dot{E} x_{\mathrm{f}}$ & 5051 \\
$\dot{E} x_{4.1}$ & 5749 \\
$\dot{E} x_{\text {dest,comb }}$ & 1254 \\
$\dot{E} x_{\mathrm{B} 1}$ & 102 \\
$\dot{E} x_{4.5}$ & 3251 \\
$\dot{W}$ & 2475 \\
$\dot{E} x_{\text {dest,gg }}$ & 125 \\
$\dot{E} x_{5}$ & 1505 \\
$E x_{\mathrm{B} 2}$ & 102 \\
$\dot{W}$ & 1561 \\
$\dot{E} x_{\text {dest,pt }}$ & 172 \\
\hline
\end{tabular}

Table 5

Exergo-economic parameters of the turboprop engine.

\begin{tabular}{lll}
\hline Item & Unit & Value \\
\hline $\mathrm{CO}$ & $\mathrm{US} \$$ & $1,000,000$ \\
$\mathrm{OM}$ & $\mathrm{US} \$ / \mathrm{yr}$ & 112,000 \\
$\mathrm{I}$ & $\%$ & 10 \\
$\mathrm{~J}$ & $\%$ & 12 \\
$\mathrm{~N}$ & $\mathrm{yr}$ & 30 \\
$\tau$ & $\mathrm{h} / \mathrm{yr}$ & 700 \\
$\mathrm{PR}$ & $\mathrm{TL} / \mathrm{kg}$ & 1.50 \\
$\mathrm{ER}$ & $\mathrm{TL} / \mathrm{US} \$$ & 1.50 \\
$\mathrm{LHV}$ & $\mathrm{kJ} / \mathrm{kg}$ & 43,400 \\
\hline
\end{tabular}

indicate the exact prices. By using the parameters listed in Table 5 and exergo-economic equations, hourly levelised capital investment cost (US\$/h), hourly operating and maintenance cost (US\$/h) and total costs of the engine and its components have been calculated as outlined in Table 6. Results from exergo-economic analysis of the engine are shown in Table 7. In this table, exergy cost rates and unit exergy costs of the engine are summarized [31].

\subsection{Life cycle assessment (LCA)}

LCA is a 'cradle-to-grave' approach for evaluating environmental performance of energy conversion systems. Environmental impact of a product during entire life cycle (including production, operation, maintenance and disposal etc.) is considered and LCA is a useful tool to assess the environmental impact of the system $[49,60]$.

Environmental impact assessment can be accomplished by using a quantitative indicator. In this paper, Eco-indicator 99 is selected. Eco-indicator 99 uses average European data and determines environmental impact according to three damage categories: (a) human health; (b) ecosystem quality; (c) natural resources. Final value of indicator represents combination of the damage to these categories and results are expressed as EcoIndicator points (pts). Greater damage corresponds to a greater value of Eco-indicator points and these values are calculated by using SimaPro 7.2 software package $[43,51,52]$.

\subsection{Exergo-environmental analysis}

Exergo-environmental impact rate $\left(\dot{B}_{k}\right)$ is the expression of environmental impact metric in Eco-indicator points per unit of time (mPts/s). It is the product of specific environmental impact (mPts/GJ) and exergy rate [57]:

$\dot{B}_{k}=\dot{b}_{k} \times \dot{E} x_{k}$

Environmental impact rate associated with work $\dot{W}$ can be calculated as follows [57]:

$\dot{B}_{\mathrm{w}}=\dot{b}_{\mathrm{w}} \times \dot{W}$

Environmental impact balance for a system can be defined as environmental impact of all input streams $\left(\dot{B}_{\text {in }}\right)$ plus the component

Table 6

Some economical costs of the engine components.

\begin{tabular}{lrccc}
\hline Component & PEC $($ US $\$)$ & $\dot{Z}_{k}^{\mathrm{CIC}}(\mathrm{US} \$ / \mathrm{h})$ & $\dot{Z}_{k}^{\mathrm{OM}}(\mathrm{US} \$ / \mathrm{h})$ & $\dot{Z}_{k}^{\mathrm{T}}(\mathrm{US} \$ / \mathrm{h})$ \\
\hline Compressor & 310,000 & 46.65 & 49.6 & 96.25 \\
Combustor & 125,000 & 18.81 & 20 & 38.81 \\
Gas turbine & 330,000 & 49.66 & 52.8 & 102.46 \\
Power turbine & 165,000 & 24.83 & 26.4 & 51.23 \\
Exhaust & 70,000 & 10.53 & 11.2 & 21.73 \\
Turboprop & $1,000,000$ & 150.48 & 160 & 310.48 \\
\hline
\end{tabular}

Source: [31]. 
Table 7

Exergy cost rates and unit exergy costs of the engine.

\begin{tabular}{llll}
\hline State no. & $\dot{E} \times(\mathrm{GJ} / \mathrm{h})$ & $\dot{C}(\mathrm{US} \$ / \mathrm{h})$ & $\dot{c}(\mathrm{US} \$ / \mathrm{GJ})$ \\
\hline 0 & 0 & 0 & 0 \\
2 & 0 & 0 & 0 \\
3 & 7.1 & 687 & 96.2 \\
3f & 16.7 & 421 & 25.2 \\
4.1 & 18.6 & 1193 & 64.1 \\
4.5 & 18.3 & 658 & 35.9 \\
5 & 10 & 314 & 31.3 \\
$\dot{W}_{\text {gg }}$ & 7.8 & 637 & 80.9 \\
$\dot{W}_{\mathrm{pt}}$ & 5 & 396 & 78.5 \\
\hline
\end{tabular}

Source: [31].

related environmental impact $(\dot{Y})$ is equal to the sum of the environmental impacts associated with output streams ( $\left.\dot{B}_{\text {out }}\right)$ [57]:

$\dot{B}_{\text {out }}=\dot{B}_{\text {in }}+\dot{Y}$

Component related total environmental impact of $k$ th component can be calculated by using following equation [57]:

$\dot{Y}_{k}^{\mathrm{TOT}}=\dot{Y}_{k}^{\mathrm{CO}}+\dot{Y}_{k}^{\mathrm{OM}}+\dot{Y}_{k}^{\mathrm{DI}}$

where $\dot{Y}_{k}^{\mathrm{CO}}$ and $\dot{Y}_{k}^{\mathrm{OM}}$ are environmental impacts of $k$ th component that occurs during construction phase and operation/maintenance phases, respectively. In this study, aircraft engines are assumed to be reutilized after depot level maintenance, hence environmental impact of the engine disposal $\dot{Y}_{k}^{\mathrm{DI}}$ is neglected. Other component of the environmental impact metric is the environmental impact rate of exergy destruction and can be found by using following equation [57]:

$\dot{B}_{\mathrm{dest}}=\dot{b}_{\mathrm{f}} \times \dot{E} x_{\mathrm{dest}}$

where $\dot{b}_{\mathrm{f}}$ is environmental impact per unit of exergy of fuel and $E x_{\text {dest }}$ is exergy destruction rate of relevant component. After $\dot{B}_{\text {dest }}$ is calculated, total environmental impact can be determined by summing $\dot{B}_{\text {dest }}$ and $\dot{Y}_{k}^{\text {TOT }}$ [57]:

$\dot{B}_{\mathrm{TOT}}=\dot{B}_{\mathrm{dest}}+\dot{Y}_{k}^{\mathrm{TOT}}$

According to control volumes given in Fig. 1 for the engine and Table 3 for the components, auxiliary equations can be formed for each component as follows:

For the compressor (c):

$\dot{B}_{2}+\dot{B}_{\mathrm{W}, \mathrm{c}}+\dot{Y}_{\mathrm{c}}^{\mathrm{TOT}}=\dot{B}_{3}+\dot{B}_{3 \mathrm{~B}}$

For the combustion chamber (comb):

$\dot{B}_{3}+\dot{B}_{\mathrm{f}}+\dot{Y}_{\mathrm{comb}}^{\mathrm{TOT}}=\dot{B}_{4}$

For the gas turbine (gg):

$\dot{B}_{4}+\dot{B}_{3 \mathrm{~B}}+\dot{Y}_{\mathrm{gg}}^{\mathrm{TOT}}=\dot{B}_{\mathrm{W}, \mathrm{gg}}+\dot{B}_{4.5}$

For the power turbine (pt):

$\dot{B}_{4.5}+\dot{Y}_{\mathrm{pt}}^{\mathrm{TOT}}=\dot{B}_{\mathrm{W}, \mathrm{pt}}+\dot{B}_{5}$

For the exhaust nozzle (exh):

$\dot{B}_{5}+\dot{Y}_{\mathrm{exh}}^{\mathrm{TOT}}=\dot{B}_{8}$

In this study, the following assumptions are taken: (a) lifetime of the engine is 30 years; (b) total annual numbers of hours year is
$700 \mathrm{~h}$ for the engine. Furthermore, environmental impact of emission is based on following four gases: (i) carbon dioxide; (ii) oxygen; (iii) water vapour; (iv) nitrogen oxides [17].

\section{Results and discussion}

Exergo-environmental analysis identifies and quantifies locations, magnitudes and sources of environmental impacts of the engine components. It is based on exergy analysis and life cycle assessment. This study presents environmental analysis of the turboprop engine by using exergy at the maximum power condition given in the literature [31,34]. From an environmental point of view, exergy analysis can be taken into account as a promising tool for the aero engines. To evaluate the environmental aspects of the turboprop engine as a function of exergy, the following parameters of the turboprop engine components are taken into consideration: (a) exergetic values, (b) economical costs, (c) exergo-economic parameters, (d) economical cost rates and unit exergy costs, (e) exergo-environmental variables.

Before analysing and evaluating the results in this section, it should first be emphasized that the principal objective of this study are not to determine the exergetic performance for the turboprop engine. Rather, studying the turboprop engine at maximum power ( $\approx 1948 \mathrm{shp}$ ) aims how much improvement is possible for the turboprop engine for better sustainable environment.

The exergo-environmental performance of the turboprop engine with free power turbine is investigated considering measured conditions such as air and fuel mass flows, temperature and pressure for the engine components. The air conditions at the compressor inlet are observed at $93 \mathrm{kPa}$ and $273 \mathrm{~K}$. In our model, the humidity is fixed at $22.77 \%$. Using cycle equations, the inlet temperature of the gas generator turbine and power turbine are calculated to be $1547 \mathrm{~K}$ and $1109 \mathrm{~K}$, respectively. The maximum power of the turboprop engine at $630 \mathrm{~N} \mathrm{~m}$ torque is set at $1948 \mathrm{shp}$. We first make some another assumptions to investigate exergoenvironmental aspects of the engine. These assumptions are made as follows:

- Type of fuel used is kerosene (Jet A-1) and its chemical formula is $\mathrm{C}_{12} \mathrm{H}_{23}$.

- The combustion reaction is complete.,

- Compressor and turbines are assumed to be adiabatic.,

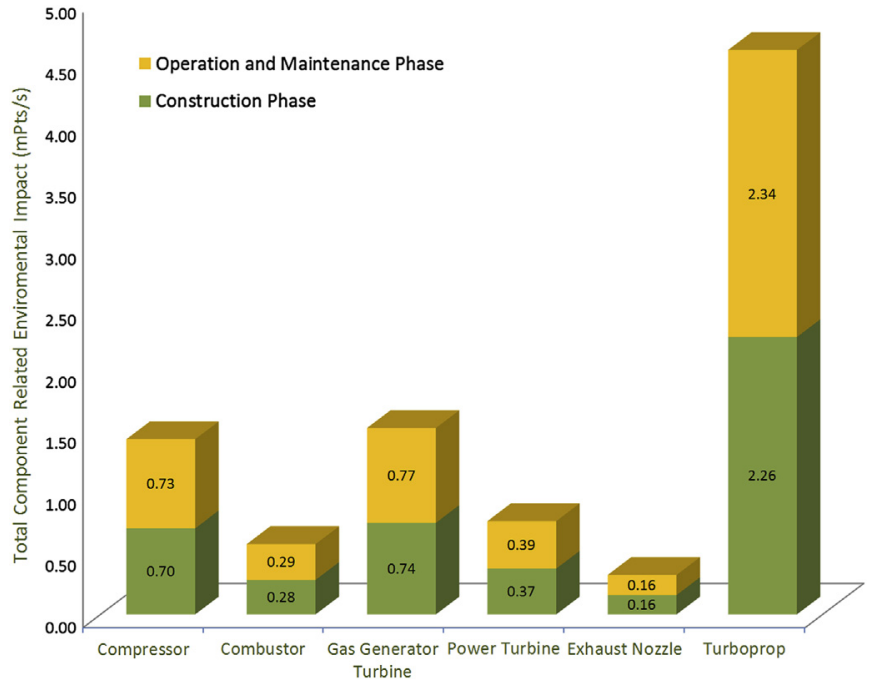

Fig. 2. Component related environmental impacts of the turboprop engine. 


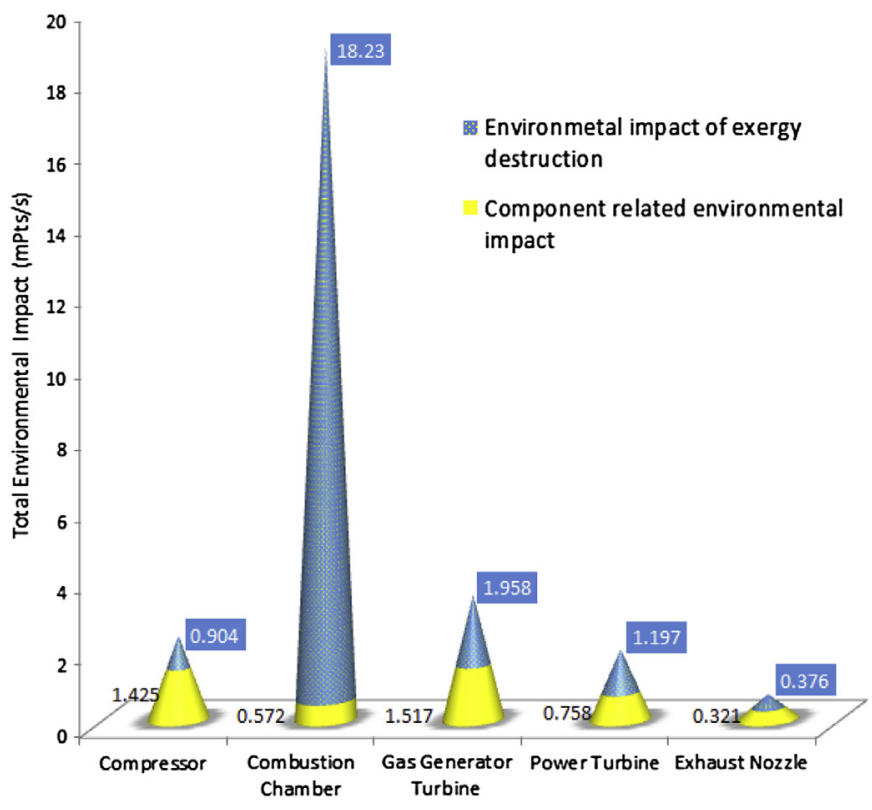

Fig. 3. Total environmental impact rates of the turboprop engine components.

- $5 \%$ of the compressor discharge air is assumed to be used as cooling and seal pressurizing purposes.

- Pumps (fuel, oil and hydraulic) and heat exchangers (fuel/air or fuel/oil) are not included in the analysis.

The main findings, which improve understanding of the exergoenvironmental behaviour of the turboprop engine at maximum shaft power as follows:

- There are two parameters of environmental impact for the turboprop engine components: (a) total component related environmental impact rates; (b) environmental impact of exergy destruction. Component related environmental impact consists of two impact rates: (i) environmental impact occurs during manufacturing of engine component; (ii) environmental impact occurs during operation/maintenance of engine components. According to Fig. 2, the unit with the greatest total component related environmental impact is found at the gas generator turbine in both constructional and operation/maintenance phases with the value of $0.74 \mathrm{mPts} / \mathrm{s}$ for the constructional phase and $0.77 \mathrm{mPts} / \mathrm{s}$ for the operational/ maintenance phases, respectively. On the other hand, the lowest total component related environmental impact is found to be in the exhaust nozzle $(0.16 \mathrm{mPts} / \mathrm{s}$ for both constructional and operation/maintenance phases). As shown in Fig. 2, in the compressor section, total component related environmental impact value is close to the gas generator turbine. From the same figure, total component related environmental impact value for the constructional phase is calculated to be $0.37 \mathrm{mPts} /$ $\mathrm{s}$ for the power turbine and $0.28 \mathrm{mPts} / \mathrm{s}$ for the combustor. Besides, total component related environmental impact value is calculated to be $0.39 \mathrm{mPts} / \mathrm{s}$ for the power turbine and $0.29 \mathrm{mPts} / \mathrm{s}$ for the combustor for the operation/maintenance phases.

- Component related environmental impact constitutes approximately $16.85 \%$ of total environmental impact. According to these rates, the compressor and gas turbine almost have same impact rate and can be considered first to improve in case of component related environmental impact.

- As it is shown in Fig. 2, total component related environmental impact for the turboprop engine is calculated to be $2.26 \mathrm{mPts} / \mathrm{s}$ for the constructional phase and $2.34 \mathrm{mPts} / \mathrm{s}$ for the operation and maintenance phase.

- Other parameters of the environmental impact are the environmental impact of exergy destructions. This part of the environmental impact is defined as main contributor to the overall environmental impact [23-25]. Fig. 3 shows total environmental impact rates of the engine components.

- Obtained results of exergo-environmental impact for turbofan engine are represented at Fig. 4. Analysis of represented variables expresses, that the combustion chamber is characterized by the highest rate of environmental impact (51.23\%), while the

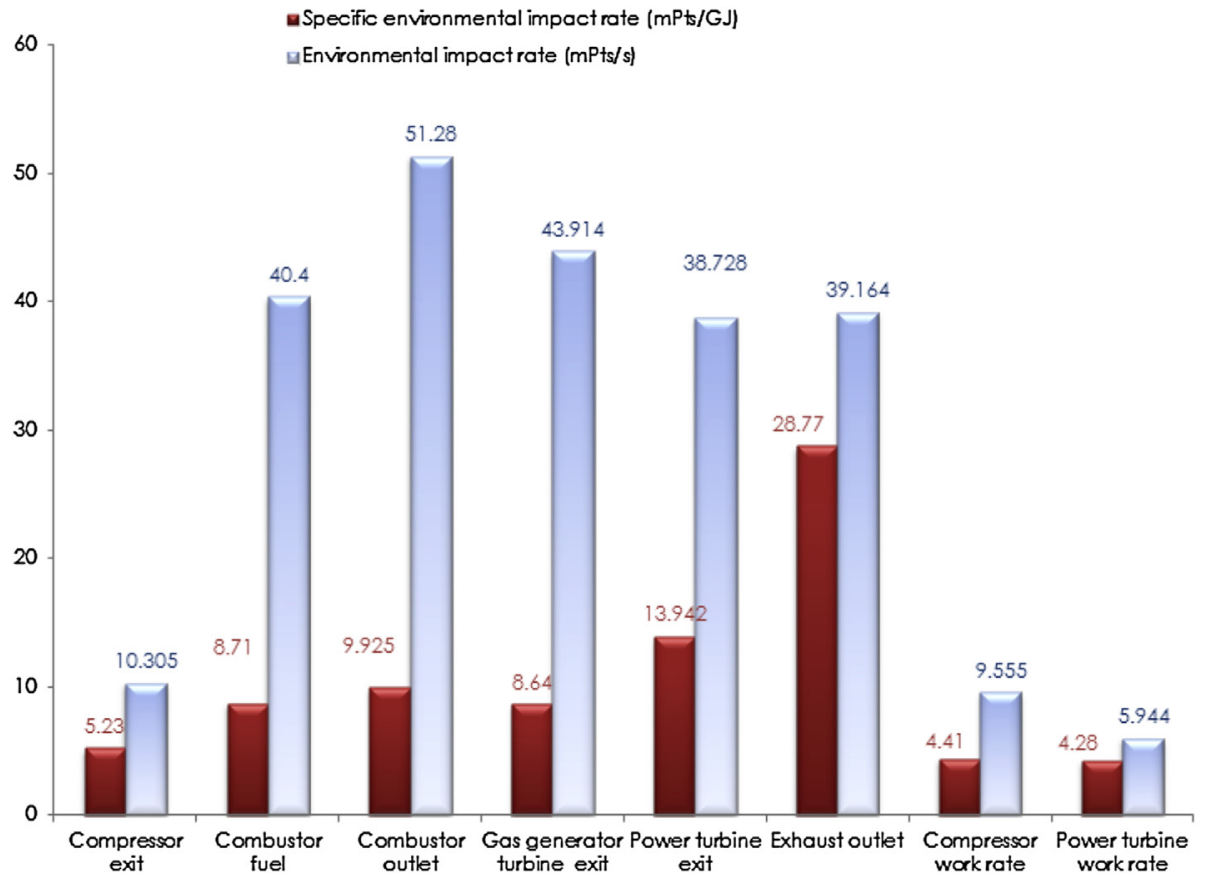

Fig. 4. Exergo-environmental variables for the engine stations. 
specific environmental impact dominates at engine exhaust outlet.

- According to exergetic results, the biggest candidate for improving is the combustion chamber. This component creates $68.98 \%$ of the overall environmental impact while $96.8 \%$ of this impact is associated with exergy destruction. These results are very parallel to literature $[31,34,35]$. In these studies, it is reported that highest exergy destruction occurs in combustion chamber due to irreversibilities result from combustion process.

- As stated previously, there is no study on exergoenvironmental analysis of aircraft engines and there is no chance to compare result of this paper to similar ones. So, exergo-environmental analysis of stationary gas turbine power plants which have similar components as aircraft engines are examined. Results of our study indicate that the combustion chamber, where the chemical reaction occurs, causes the largest portion of total environmental impact of a turboprop aircraft engine.

\section{Conclusions}

To develop approaches that effectively reduce engine environmental effect of aircraft, it is necessary to understand the mechanisms that have enabled improvements in thermodynamic efficiency of aircraft propulsion systems. In the present paper, exergo-environmental method is applied for the first time to an aircraft turboprop engine. This study has presented environmental aspects for a turboprop engine commonly used in regional transportation as well.

Approximately $17 \%$ of total environmental impact of turboprop engine is result of component related environmental impact and remaining part is result of exergy destructions of the turboprop engine components. Compressor, combustion chamber, gas generator turbine, power turbine and exhaust nozzle create $9 \%$, $69 \%, 13 \%, 7 \%, 2 \%$ of total environmental impact of the engine, respectively.

Results have indicated that combustion chamber has the highest priority for improvement. Beside conventional analysis, advanced exergo-environmental analysis which is considered as a valuable supplement to conventional analysis can be applied to get more accurate results by defining avoidable and unavoidable parts of environmental impacts

Researchers and scientists are working hard to minimize anthropogenic degradation of the environment. One solution is alternative energy sources to fossil fuels like biofuels or hybrid electric propulsion systems. However in short and medium term, feasible application of these alternative energy sources to the aircraft power plants seems unrealistic, and that means dependence to the fossil fuel appears to be inevitable. The development of exergo-environmental analysis for aircraft propulsion systems can play a significant role in the investigation of the possibilities and advantages of green regional aircraft. Hence, approaches like exergy-based analysis that contribute to improve environmental effects of aircraft engines can offer best solutions.

\section{Acknowledgement}

The authors are grateful to Anadolu University and TUSAS Engine Industries (TEI) in Eskisehir city of Turkey and National Aviation University in Kyiv for full support throughout the preparation of this study, while they would like to thank the reviewers for their valuable comments, which helped in increasing the quality of the paper.

\section{Nomenclature}

$\mathrm{AB} \quad$ afterburner

$\dot{b} \quad$ specific environmental impact rate $(\mathrm{mPts} / \mathrm{GJ})$

$\dot{B} \quad$ environmental impact rate (mPts/s)

BPR bypass ratio

$\dot{C} \quad$ cost rate of exergy stream

CHP combined heat and power

CT7-9C model of the turboprop aircraft engine

ER exchange rate

$\dot{E} x \quad$ exergy rate $(\mathrm{kW})$

GHG greenhouse gases

I interest rate

$j \quad$ salvage rate

$k \quad k$ th component

$\mathrm{km} \quad$ kilometers

$\mathrm{kph} \quad$ kilometers per hour

LCA life cycle assessment

LHV lower heating value $(\mathrm{kJ} / \mathrm{kg})$

LTO landing and take-off

mph miles per hour

$N \quad$ engine lifetime

$p \quad$ pressure

PR fuel price

PEC purchased equipment cost

pts eco-indicator points

shp shaft horsepower

SOFC solid oxide fuel cell

$T$ the total number of hours of the engine

$\tau \quad$ temperature

W $\quad$ work $(\mathrm{kW})$

$\dot{Y} \quad$ component related environmental impact (mPts/s)

$\dot{Z} \quad$ capital cost flow

$\begin{array}{ll}\text { Superscripts and subscripts } \\ \text { c } & \text { compressor } \\ \text { comb } & \text { combustion chamber } \\ \text { CO } & \text { construction } \\ \text { dest } & \text { destruction } \\ \text { DI } & \text { disposal } \\ \text { exh } & \text { exhaust nozzle } \\ \text { f } & \text { fuel } \\ \text { gg } & \text { gas turbine } \\ \text { in } & \text { input } \\ k & \text { kth component } \\ \text { OM } & \text { operation and maintenance } \\ \text { out } & \text { output } \\ \text { pt } & \text { power turbine } \\ \text { TOT } & \text { total } \\ \text { w } & \text { work } \\ 0 & \text { dead state (environment) conditions } \\ 0,1,2, \ldots, & \text { B1 station numbering of the engine }\end{array}$

\section{References}

[1] NASA. Green aviation: a better way to treat the planet. Available from $<$ http://www.aeronautics.nasa.gov/pdf/green_aviation_fact_sheet_web.pdf $>$.

[2] Enviro; 2011. Available from: <http://www.enviro.aero/Content/Upload/File/ BeginnersGuide_Biofuels_Web $>$.

[3] IATA; 2011. Available from: <http://www.boeing.com/commercial/cmo/ forecast_summary.html >.

[4] Boeing; 2011. Available from: <http://www.boeing.com >.

[5] Leea J, Ian J, Waitz A, Brian Y, Kim C, Gregg G, et al. System for assessing aviation"s global emissions (SAGE), part 2: uncertainty assessment. Transport Res D-Tr E 2007;12:381-95.

[6] USHP; 2006. Available from:<http://www.house.gov/transportation/aviation/ 02-15-06/02-15-06memo.html $>$. 
[7] Parker R. From blue skies to green skies: engine technology to reduce the climate-change impacts of aviation. Technol Anal Strateg Manage 2009;21: $61-78$.

[8] Becerra AT, Martinez PP, Bravo XL, Pastor IO. A methodology for territorial distribution of $\mathrm{CO}_{2}$ emission reductions in transport sector. Int J Energy Res 2012;14:1298-313.

[9] Schipper L, Scholl L, Price L. Energy use and carbon emissions from freight in 10 industrialized countries: an analysis of trends from 1973 to 1992 . Transport Res D-Tr E 1997;1:57-76.

[10] Timilsina GR, Shrestha A. Development factors affecting transport sector $\mathrm{CO}_{2}$ emissions growth in Latin American and Caribbean countries: an LMDI decomposition analysis. Int J Energy Res 2009;33:396-414.

[11] Ayres RU, Ayres LW, Martina K. Eco-thermodynamics: exergy and life cycle analysis. INSEAD, Center for the Management of Environmental Resources; 1996. Working paper 961041.

[12] Ahmadi P, Dincer I, Rosen MA. Exergy, exergoeconomic and environmental analyses and evolutionary algorithm based multi-objective optimization of combined cycle power plants. Energy 2011;36:5886-98.

[13] Ptasinski KJ, Koymans MN, Verspagen HHG. Performance of the Dutch energy sector based on energy, exergy and extended exergy accounting. Energy 2006;31:3135-44.

[14] Babikian R, Lukachko SP, Waitz IA. The historical fuel efficiency characteristics of regional aircraft from technological, operational, and cost perspectives. J Air Transp Manag 2002;8:389-400.

[15] Peeters PM, Middel J, Hoolhorst A., Fuel efficiency of commercial aircraft: an overview of historical and future trends; 2005. NLR-CR-2005-669.

[16] MIT; 2011. Available from: <http://web.mit.edu/airlines/analysis/analysis_ airline_industry.html>.

[17] Midilli A, Dincer I. Development of some exergetic parameters for PEM fue cells for measuring environmental impact and sustainability. Int J Hydrogen Energy 2009;34:3858-72.

[18] Midilli A, Dincer I. Effects of some micro-level exergetic parameters of a PEMFC on the environment and sustainability. Int J Global Warm 2010;2(1): 65-80.

[19] Norberg S, Tamm G, Highley J, Rounds M, Boettner D, Arnas O. Teaching thermodynamics via analysis of the west point power plant. Int J Green Energy 2009;6(3):230-44.

[20] Dincer I, Rosen MA. Worldwide perspective on energy, environment and sustainable development. Int J Energ Res 1998;22:1305-21.

[21] Ao Y, Gunnewiek L, Rosen MA. Critical review of exergy-based indicators for the environmental impact of emissions. Int J Green Energy 2008;5:87-104.

[22] Dincer I, Rosen MA. Thermodynamic aspects of renewables and sustainable development. Renew Sust Energ Rev 2005;9:169-89.

[23] Ji X, Chen GQ, Chen B, Jiang MM. Exergy-based assessment for waste gas emissions from Chinese transportation. Energy Policy 2009;37:2231-40.

[24] Ayres RU, Ayres LW, Martina K. Exergy, waste accounting, and lifecycle analysis. Energy 1998;23(5):355-63.

[25] Rosen MA, Dincer I, Kanoglu M. Role of exergy in increasing efficiency and sustainability and reducing environmental impact. Energy Policy 2008;36: $128-37$.

[26] Wall G. Exergy tools, proceedings. Institution of Mechanical Engineering; 2003. p. $125-36$.

[27] Soylu S. Estimation of Turkish road transport emissions. Energy Policy 2007;35:4088-94.

[28] Federici M, Ulgiati S, Basosi R. A thermodynamic, environmental, and material flow analysis of the Italian highway and railway transport systems. Energy 2008;33:760-75.

[29] Embraer, Market outlook 2011-2030; 2011. Available from: <http://www. embraer.com>.

[30] Deloitte, Global aerospace market outlook and forecast report; 2012. Available from: <http://www.aiac.ca $>$.

[31] Aydın H, Turan O, Midilli A, Karakoc TH. Component-based exergetic measures of an experimental turboprop/turboshaft engine for propeller aircrafts and helicopters. Int J Exergy 2012;11:322-48.

[32] Favrat D, Marechal F, Epelly O. The challenge of introducing an exergy indicator in a local law on energy. Energy 2008;33:130-6.

[33] Federici M, Ulgiati S, Basosi R. Air versus terrestrial transport modalities: an energy and environmental comparison. Energy 2009;34:1493-503.
[34] Aydın H, Turan O, Midilli A, Karakoc TH. Exergetic and exergo-economic analysis of a turboprop engine: a case study for CT7-9C. Int J Exergy 2012;11:69-88.

[35] Ballı O, Aras H, Hepbaslı A. Exergetic and exergoeconomic analysis of an aircraft jet engine (AJE). Int J Exergy 2008;5:567-81.

[36] Bejan A, Siems DL. The need for exergy analysis and thermodynamic optimization in aircraft development. Int J Exergy 2001;1:14-24.

[37] Cesare T, Paolo AR, Luiz F, Oliveira SDJ. Exergy and thermoeconomic analysis of a turbofan engine during a typical commercial flight. Energy 2010;35:952-9.

[38] Diango A, Perilhon C, Descombes G, Danho E. Application of exergy balances for the optimization of non-adiabatic small turbomachines operation. Energy 2011;36:2924-36.

[39] Etele J, Rosen MA. Sensitivity of exergy efficiencies of aerospace engines to reference environmental selection. Int J Exergy 2001;1:91-9.

[40] Rosen MA, Etele J. Aerospace systems and exergy analysis: applications and methodology development needs. Int J Exergy 2004;1:411-25.

[41] Roth BA, Mavris DN., A comparison of thermodynamic loss models applied to the J79 turbojet engine. Joint propulsion conference and exhibit, 36th, Huntsville, AL; 16-19 July 2000 [Conference paper].

[42] Roth B, Mavris D. A work availability perspective of turbofan engine performance. AIAA publication no. 0391. American Institute of Aeronautics and Astronautics; 2001.

[43] Turan O. Effect of reference altitudes for a turbofan engine with the aid of specific-exergy based method. Int J Exergy 2012;11:252-70.

[44] Turan O. Exergetic effects of some design parameters on the small turbojet engine for unmanned air vehicle applications. Energy 2012;46:51-61.

[45] Altuntas O, Karakoc TH, Hepbasli A. Exergetic, exergoeconomic and sustainability assessment of piston-prop aircraft engine. Int J Thermal Sci Technol 2012;32(2):133-43.

[46] Ahmadi P, Dincer I. Thermodynamic and exergoenvironmental analyses, and multi-objective optimization of a gas turbine power plant. Appl Thermal Eng 2011;31:2529-40.

[47] Boyano A, Morosuk T, Blanco-Marigorta AM, Tsatsaronis G. Conventional and advanced exergoenvironmental analysis of a steam methane reforming reactor for hydrogen production. Int J Cleaner Prod 2012;20:152-60.

[48] Boyano A, Morosuk T, Blanco-Marigorta AM, Tsatsaronis G. Exergoenvironmental analysis of a steam methane reforming process for hydrogen production. Energy 2011;36:2202-14.

[49] Meyer L, Tsatsaronis G, Buchgeister J, Schebek L. Exergoenvironmental analysis for evaluation of the environmental impact of energy conversion systems. Energy 2009;34:75-89.

[50] Ahmadi P, Dincer I, Rosen MA. Exergoenvironmental analysis of a trigeneration system based on micro gas turbine and organic rankine cycles. Proceedings of the global conference on global warming, Portugal; 2011.

[51] Petrakopoulou F, Tsatsaronis G, Morosuk T, Paitazoglou C. Environmental evaluation of a power plant using conventional and advanced exergy-based methods. Energy 2012;45:23-30.

[52] Altuntas O, Karakoc TH, Hepbasli A. Exergoenvironmental analysis of pistonprop aircrafts. Exergy Int J 2012;10(3):290-8.

[53] Restrepo A, Miyake R, Kleveston F, Bazzo E. Exergetic and environmental analysis of a pulverized coal power plant. Energy 2012;45:195-202.

[54] Ahmadi P, Dincer I. Exergoenvironmental analysis and optimization of a cogeneration plant system using Multimodal Genetic Algorithm (MGA). Energy 2010;35:5161-72.

[55] Sforza PM. Theory of aerospace propulsion. Elseiver; 2011.

[56] Kroes MJ, Wild TW. Aircraft power plants. USA: Glencoe/McGraw-Hill; 1995

[57] Tsatsaronis G. Exergoeconomics and exergoenvironmental analysis. In: Bakshi BR, Gutowski TG, Sekulic DP, editors. Thermodynamics and the destruction of sources. Cambridge University Press; 2011,377-,401.

[58] Cassetti G, Colombo E. Comparison between traditional methodologies and advanced exergy analyses for evaluating efficiency and externalities of energy systems. Proceedings of ECOS, Italy; 2012.

[59] Bejan A, Tsatsaronis G, Moran M. Thermal design and optimization. USA: Wiley; 1996.

[60] Life cycle assessment: principles and practise. U.S. Environmental Protection Agency (EPA). <http://www.epa.gov/nrmrl/std/lca/lca.html>; May 2006. 